\title{
LGU'S FUNCTIONS IN PRESERVATION OF CONSCIOUSNESS ON CULTURE OF THE CITIZENS
}

\author{
Timothy John A. Litan \\ Faculty, STI College Sta. Cruz
}

Article DOI: https://doi.org/10.36713/epra7620

DOI No: 10.36713/epra7620

\begin{abstract}
The aim of this study is to understand and identify the relationship of the LGU's functions to the preservation of the consciousness of the citizens. It sought to answer the following questions, (1) the mean level of the LGU's functions in the preservation of consciousness on the culture of the citizens, (1.1) education, (1.2) laws implementation, (1.3) cultural heritage; (2) the mean level of the citizens' consciousness of their culture, (2.1) customs, (2.2) habits, (2.3) values, (3) the significant relationship between the LGU's functions in the preservation of consciousness on the culture of the citizens.

Descriptive method of research was used to analyze the data systematically. The researcher looked for the population of the Pagsanjan, Laguna. From the population, the researcher used purposive sampling were in the members of the population are selected based on the objective of the study. The researcher formulated the self-made questionnaire and made it validated by set of experts before it was distributed through MS Forms. The approval of the municipal mayor of Pagsanjan, Laguna was also seeking by the respondents as courtesy for the implementation of the study. After the data collection, the researcher analyzed, presented and interpreted them.

The best performed LGU's function identified by the respondents to preserve the culture is laws implementation which rated 4.73 followed by education which rated 4.33 , both are in a very high extend and lastly is the preservation of cultural heritage that rated 3.88 as high extent. The respondents are said to be most conscious in their culture in terms of both Habits and Values which rated 4.42 as very high while customs rated 4.07 as high.

$L G U$ 's functions in the preservation of the culture provide a "positive relationship" to the citizens" consciousness of their culture. The hypothesis which stated that there is no significant relationship between the $L G U$ 's functions in the preservation of consciousness on the culture of its citizens is "not supported".

KEYWORDS: Cultural Heritage, Custom, Education, Habit, Laws Implementation, Programs, Values
\end{abstract}

\section{INTRODUCTION}

The set of shared attitudes, values, goals, and practices that characterizes an institution or organization. This is how the Merriam-Webster dictionary defined what is culture is. Culture is the sole definition of who are the people in a certain place, how they deal with each other and why they are probably still existing.

Unfortunately, the existence of what other people say "cultural amnesia" is really transpiring. This expression would likely come from the lips of someone who regrets the tendency of some people to overlook about their customs, roots, particularly the values, habits, restrictions, and ideals which may have once been embraced by a people-group as a whole but have now been forgotten and replaced by different customs, habits, values, and ideals. Dejectedly, modern times are threatening to wipe out the things that have made us exceptionally Filipino.

Republic Act No. 10066 or the National Cultural Heritage Act of 2009, an act providing for the protection and conservation of the national cultural heritage, strengthening the National Commission for Culture and the Arts (NCCA) and its affiliated cultural agencies, and for other purposes have the following objectives: (a) protect, 


\section{SJIF Impact Factor 2021: 8.013| ISI I.F.Value:1.241| Journal DOI: 10.36713/epra2016 ISSN: 2455-7838(Online) EPRA International Journal of Research and Development (IJRD)

preserve, conserve and promote the nation's cultural heritage, its properly and histories, and the ethnicity of local communities; (b) establish and strengthen cultural institutions; and (c) protect cultural workers and ensure their professional development and well-being. With the help of this law, it will protect and preserve the culture of the country and its people's practices and beliefs. Different institutions of the government are expected to create programs that will help to preserve the country's culture. But is it enough? Are the ways and the current programs that the government implements is enough to meet its goals in preserving the country's culture? This study will focus on the LGU's functions in preservation of consciousness on culture of the citizens.

\section{OBJECTIVE OF THE STUDY}

The main purpose of the study was to determine the LGU's functions in preservation of consciousness on the culture of the citizens.

Specifically, the study seeks to answer the following questions:

1. What is the mean level of the LGU's functions in the preservation of consciousness on the culture of the citizens in terms of:

1.1 education;

1.2 laws implementation; and

1.3 cultural heritage?

2. What is the mean level of the citizens' consciousness of their culture in terms of:

2.1 customs;

2.2 habits; and

2.3 values?

3. Is there a significant relationship between the LGU's functions in the preservation of consciousness on the culture of the citizens?

\section{RELATED LITERATURE}

Lustig (2013) notes that cultural identities are central to a person's sense of self. That is because cultural identities "are central, dynamic, and multifaceted components of one's self concept". Lustig also points out that cultural identities are dynamic, and they exist within a changing social context. As a result, a person's identity changes as do one's ongoing experiences in life. Other researchers describe cultural identity as referring to the content of values as guiding principles, to meaningful symbols, and to life styles that individuals share with others, though not necessarily within recognizable groups. This process involves learning about and accepting traditions, heritage, language. Religion, ancestry, aesthetics, thinking patterns, and social structure of a culture. The culture becomes a part of their self-concept. Cultural identity theory may not account for the fact that different individuals and groups may not react to or interpret events, happenings, and attitudes in the same ways as other individuals or groups.

Gaivoron (2018) states in his study that preservation is not possible without education. It is the strongest tool. Their mission is to empower people to recognize the significance of historic resources, to preserve them for future generations, and to integrate them into everyday life through redevelopment, lifelong learning, and community conversations. There is a strong need to assess cultural practices says Obioha (2012); traditional laws and taboos of the people in protected areas, and how they have assisted conservation in the past. To understand how such practices could be strengthened and incorporated into natural resources management and conservation strategies, there is a need to have a general overview of existing practices. is cultural heritage. More to the point in Cros (2012) study states that museums are influenced by their condition in terms of place, time and people/workers and by recent consensus of what things in museums indicate. In the study made by Hays (2015) and Zimmermann (2017) proves that Philippines is rich in culture and customs that they have. It is maybe because of the different conquerors that makes the whole country formed different practices and customs. Customs is part of the culture that creates identity. Practices are part of its custom and customs is part of the culture. It can say that practices or customs are those practices made by different people. Wamimbi (2017) states in his study that having low societal agreement in cultural values propose that the field's leading paradigm culture as shared values is a fallacy. So it is important to develop the consciousness one person have in their culture. Moreover Morris (2014) states that the public appearance of personal values that groups of people find important in their everyday lives, lay the fundamentals of law, custom and tradition. 
RESULTS AND DISCUSSION

Level of Lgu's Functions in Culture Preservation

Table 1. Level of LGU's Functions in the Preservation of the Culture as to Education

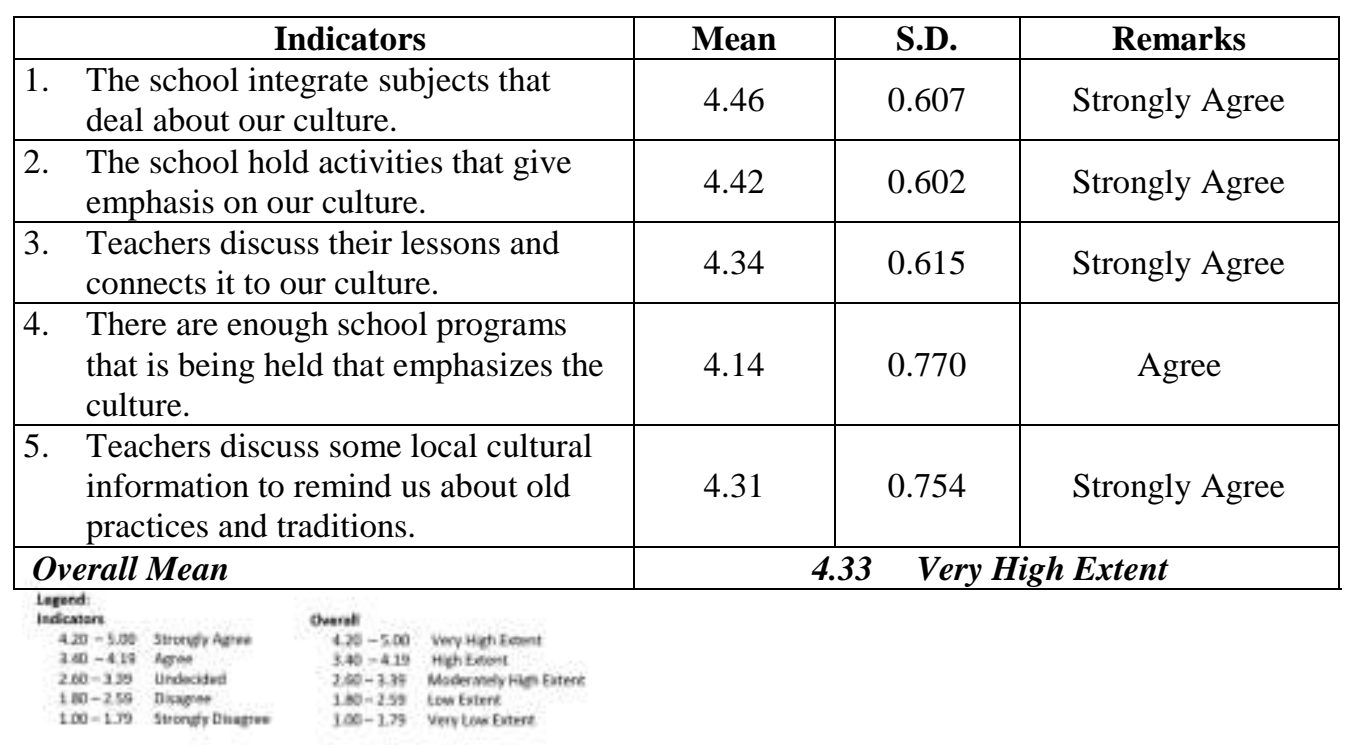

The overall mean of 4.33 signifies that the LGU performed their functions in the preservation of the culture in terms of education at a very high extent. This means that the LGU's functions in terms of education is showing good impact to the citizens. The citizens can see and appreciates the efforts being made by the LGU to preserve its culture. It also shows that education is a great factor that can be considered that can help the LGU officials preserve the culture.

Table 2. Level of LGU's Functions in the Preservation of the Culture as to Laws Implementation

\begin{tabular}{|l|c|c|c|}
\hline \multicolumn{1}{|c|}{ Indicators } & Mean & S.D. & Remarks \\
\hline $\begin{array}{l}\text { 1. } \\
\text { Philippines implements laws about the } \\
\text { preservation of our culture. }\end{array}$ & 4.96 & 0.265 & Strongly Agree \\
\hline $\begin{array}{l}\text { 2. } \\
\text { The local officials put up programs that } \\
\text { deal with preservation of our culture. }\end{array}$ & 4.45 & 0.975 & Strongly Agree \\
\hline 3. $\begin{array}{l}\text { Local officials lead celebration of festival } \\
\text { held every year for cultural preservation. }\end{array}$ & 4.82 & 0.575 & Strongly Agree \\
\hline $\begin{array}{l}\text { 4. } \\
\text { National Commission for Culture and the } \\
\text { Arts (NCCA) is the overall policy making } \\
\text { body in coordinating, and grants giving } \\
\text { agency for the preservation, development } \\
\text { and promotion of Philippine arts and } \\
\text { culture. }\end{array}$ & 4.75 & 0.668 & Strongly Agree \\
\hline $\begin{array}{l}\text { Laguna Tourism Culture Arts and Trade } \\
\text { Office (LTCATO) is assigned in } \\
\text { preserving the culture of the province of } \\
\text { Laguna. }\end{array}$ & 4.65 & 0.764 & Strongly Agree \\
\hline Overall Mean & $\mathbf{4 . 7 3}$ Very High Extent & \\
\hline
\end{tabular}




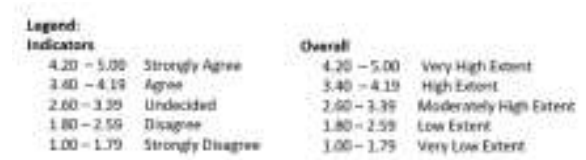

The overall mean of 4.73 signifies that the LGU performed their functions in the preservation of the culture in terms of laws implementation at a very high extent. This means that the citizens are very much aware of the laws implemented in their municipality. The LGU implementing their laws very well as part of their efforts in the preservation of the culture.

Table 3. Level of LGU's Functions in the Preservation of the Culture as to Preservation of Cultural Heritage

\begin{tabular}{|l|c|c|c|}
\hline \multicolumn{1}{|c|}{ Indicators } & Mean & S.D. & Remarks \\
\hline 1. & 4.46 & 0.564 & Strongly Agree \\
$\begin{array}{l}\text { The Philippines has establishments/ } \\
\text { culture. }\end{array}$ & 3.32 & 1.069 & Undecided \\
\hline $2 . \quad \begin{array}{l}\text { Some museums were built near or } \\
\text { located in my area. }\end{array}$ & 3.78 & 0.871 & Agree \\
\hline $3 . \quad \begin{array}{l}\text { There are enough museums which are } \\
\text { built in the whole country. }\end{array}$ & 3.85 & 0.904 & Agree \\
\hline $4 . \quad \begin{array}{l}\text { Ancestral Houses are being preserved } \\
\text { in Pagsanjan, Laguna. }\end{array}$ & 3.98 & 0.767 & Agree \\
\hline $5 . \quad \begin{array}{l}\text { Local officials are doing their best to } \\
\text { promote the cultural heritage in } \\
\text { Pagsanjan, Laguna. }\end{array}$ & \multicolumn{3}{|c|}{$\mathbf{3 . 8 8}$ High Extent } \\
\hline Overall Mean &
\end{tabular}

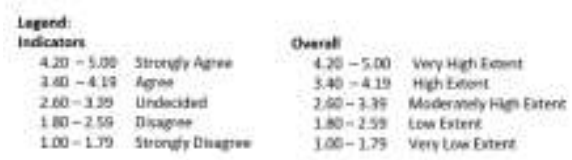

The overall mean of 3.88 signifies that the LGU performed their functions in the preservation of the culture in terms of preservation of cultural heritage at a high extent. This means that there are good but not enough cultural heritage sights in the place to preserve the culture. The respondents also agree that museums are barely seen in their place. Although it measures a good overall mean, still in all the variables it renders the lowest value. Part of this is the modernization that is happening in the place that is in out of control of the LGUs.

Level of the Citizens' Consciousness of Their Culture

Table 4. Level of the Citizens' Consciousness of Customs in their Culture

\begin{tabular}{|c|c|c|c|}
\hline Indicators & Mean & S.D. & Remarks \\
\hline $\begin{array}{l}\text { 1. } \begin{array}{l}\text { Relying on superstitious beliefs have been } \\
\text { displayed to help promote a positive mental } \\
\text { attitude. }\end{array} \\
\end{array}$ & 3.22 & 1.078 & Undecided \\
\hline $\begin{array}{l}\text { 2. Celebrating fiestas in every place to } \\
\text { commemorate the Saints is still part of our } \\
\text { customs. }\end{array}$ & 4.18 & 0.926 & Agree \\
\hline Being hospitable is still practiced in our home. & 4.58 & 0.574 & Strongly Agree \\
\hline 4. Bayanihan is still being observed in our place. & 4.22 & 0.735 & Strongly Agree \\
\hline $\begin{array}{l}\text { 5. Folk tales and other oral lore are still alive in } \\
\text { my mind. }\end{array}$ & 4.13 & 0.744 & Agree \\
\hline Overall Mean & & 4.07 & High \\
\hline
\end{tabular}




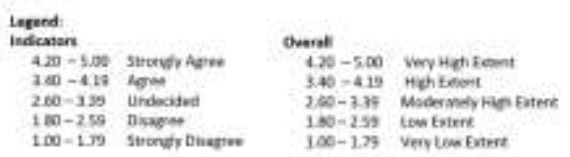

The overall mean of 4.07 signifies the Citizens' Consciousness of Customs in their Culture at a moderately high. This means that the customs of the citizens in their place are still moderately visible. There are still customs of their place where they are still practicing in this modern time. It is also remarkable that the citizens are starting not to believe in superstitious beliefs even though it is one the customs that they have.

Table 5. Level of the Citizens' Consciousness of Habits in their Culture

\begin{tabular}{|c|c|c|c|}
\hline \begin{tabular}{|l} 
Indicators \\
\end{tabular} & Mean & S.D. & Remarks \\
\hline $\begin{array}{l}\text { 1. The use of "po" and "opo" every time } \\
\text { having a conversation with older } \\
\text { persons is still practiced by the young } \\
\text { generations. }\end{array}$ & 4.41 & 0.783 & Strongly Agree \\
\hline $\begin{array}{l}\text { 2. "Pagmamano" to the elderlies } \\
\text { whenever and wherever meeting them } \\
\text { is still practiced. }\end{array}$ & 4.20 & 0.931 & Strongly Agree \\
\hline $\begin{array}{l}\text { 3. Using bare hands when having meals } \\
\text { instead of using a spoon and fork is } \\
\text { still practiced especially at home. }\end{array}$ & 4.33 & 0.780 & Strongly Agree \\
\hline $\begin{array}{l}\text { 4. Rice as staple food is still being } \\
\text { considered. }\end{array}$ & 4.70 & 0.478 & Strongly Agree \\
\hline $\begin{array}{l}\text { 5. Bringing gifts from the destination to } \\
\text { people back home is still substantial } \\
\text { as a sign of generosity. }\end{array}$ & 4.48 & 0.608 & Strongly Agree \\
\hline Overall Mean & & .42 & High \\
\hline
\end{tabular}

\begin{tabular}{|c|c|c|c|}
\hline $\begin{array}{l}\text { Lefend: } \\
\text { indicasans }\end{array}$ & & Coenst & \\
\hline $4.20-506$ & Struter Agee & $1.70-5,00$ & Wey Hati Eemt \\
\hline $3 \times 0-149$ & now & $3.40-4.19$ & Mititeont \\
\hline $260=130$ & Undocited & $200-3.34$ & Modermely fin fatere \\
\hline $100-250$ & nxagen & $100-2.59$ & tew tritere \\
\hline $1 \infty=1.29$ & Stronsty Diatrer & $100-179$ & Verv tees fotrert \\
\hline
\end{tabular}

The overall mean of 4.42 signifies the Citizens' Consciousness of Habits in their Culture at a very high. This means that the habits of the citizens as to have as their culture are still manifested nowadays.

Table 6. Level of the Citizens' Consciousness of Habits in their Culture

\begin{tabular}{|cl|c|c|c|}
\hline \multicolumn{1}{|c|}{ Indicators } & Mean & S.D. & Remarks \\
\hline 1. & 4.58 & 0.616 & Strongly Agree \\
\hline $\begin{array}{l}\text { Giving respect to the elderlies is still } \\
\text { being practiced. }\end{array}$ & 4.54 & 0.766 & Strongly Agree \\
\hline $\begin{array}{l}\text { Valuing religion is a sign of my faith to } \\
\text { God. }\end{array}$ & 4.73 & 0.467 & Strongly Agree \\
\hline $\begin{array}{l}\text { Valuing my family even though I } \\
\text { have/will have my own family. }\end{array}$ & 3.91 & 0.996 & Agree \\
\hline $4 . \quad \begin{array}{l}\text { Females are expected more to lend a hand } \\
\text { in household works than males. }\end{array}$ & 4.36 & 0.708 & Strongly Agree \\
\hline 5. $\begin{array}{l}\text { Debt of gratitude is considered an } \\
\text { important value to appropriately repay } \\
\text { someone who has done one a favor. }\end{array}$ & \multicolumn{3}{|c|}{$\mathbf{4 . 4 2}$ Very High } \\
\hline Overall Mean & \multicolumn{2}{|l}{} \\
\hline
\end{tabular}




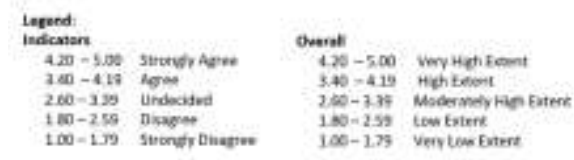

The overall mean of 4.42 signifies the Citizens' Consciousness of Values in their Culture at a very high. This means that values from their culture is still being pass through the present generation.

\section{Relationship between the LGU's Functions in the Preservation of Culture and the Citizens' Level of Consciousness to their Culture}

Table 7. Relationship between the LGU's Functions in the Preservation of Culture and the Citizens' Level of Consciousness to their Culture

\begin{tabular}{|c|c|c|c|c|c|c|c|c|c|}
\hline \multirow[b]{2}{*}{ Roles } & \multicolumn{3}{|c|}{ Customs } & \multicolumn{3}{|c|}{ Habits } & \multicolumn{3}{|c|}{ Values } \\
\hline & $\begin{array}{c}\text { r- } \\
\text { value }\end{array}$ & $\begin{array}{c}\mathrm{p} \text { - } \\
\text { value }\end{array}$ & Analysis & $\begin{array}{c}\mathrm{r}- \\
\text { value }\end{array}$ & $\begin{array}{c}\mathrm{p}- \\
\text { value }\end{array}$ & Analysis & $\begin{array}{c}r- \\
\text { value }\end{array}$ & $\begin{array}{c}\mathrm{p}- \\
\text { value }\end{array}$ & Analysis \\
\hline Education & 0.566 & 0.000 & $S$ & 0.426 & 0.000 & $s$ & 0.495 & 0.000 & $S$ \\
\hline $\begin{array}{l}\text { Laws } \\
\text { Implementation }\end{array}$ & 0.501 & 0.000 & $s$ & 0.452 & 0.000 & $s$ & 0.460 & 0.000 & $S$ \\
\hline \begin{tabular}{l|l} 
Cultural \\
Heritage
\end{tabular} & 0.472 & 0.000 & $S$ & 0.397 & 0.000 & $S$ & 0.503 & 0.000 & $S$ \\
\hline $\begin{array}{l}\text { Degree of Corre } \\
\pm 0.80- \pm 1.0 \\
\pm 0.60- \pm 0.7 \\
\pm 0.40- \pm 0.5 \\
\pm 0.20- \pm 0.3 \\
\pm 0.00- \pm 0.1\end{array}$ & $\begin{array}{l}\text { elation: } \\
0 \text { Very } \\
9 \text { Stro } \\
9 \text { Mod } \\
9 \text { Wea } \\
19 \text { Very }\end{array}$ & $\begin{array}{l}\text { strong } \\
\text { ng } \\
\text { erate } \\
k \\
\text { weak }\end{array}$ & & & & & & & \\
\hline
\end{tabular}

Reflected in the descriptive tables are the extent to which the LGU promote the culture and the citizens' consciousness of the customs, habits, and values. It is interesting to note that the LGU's functions in the preservation of the culture in terms of education has positive and moderate correlation with the citizens' consciousness of the customs $(r=0.566, p=0.000)$. The relationship is significant. This means that the LGU's function in terms of education has been done well to preserve the consciousness of the culture in terms of customs.

Similarly, there exists positive and moderate correlation between the LGU's functions in the preservation of the culture in terms of education and the citizens' consciousness of the habits $(r=0.426, p=0.000)$. The relationship is significant. This means that the LGU's function in terms of education has been done well to preserve the consciousness of the culture of the citizens in terms of habits.

It is acceptable that the citizens really have the chance to change their habits but because of the good efforts being done by the LGUs then it still the habits that they have today from the past.

The LGU's functions in the preservation of the culture in terms of education and the citizens' consciousness of values $(r=0.495, p=0.000)$ were denoted by a positive and moderate correlation. The relationship is significant This means that the LGU's function in terms of education has been done well to preserve the consciousness of the culture of the citizens in terms of values.

Also, reflected in the descriptive tables are the extent to which the LGU promote the culture and the citizens' consciousness of the customs, habits, and values. It is remarkable to mention that the LGU's functions in the preservation of the culture in terms of laws implementation has positive and moderate correlation with the citizens' consciousness of the customs $(r=0.501, p=0.000)$. The relationship is significant. This means that the LGU's function in terms of laws implementation has been done well to preserve the consciousness of the culture of the citizens in terms of customs. 


\section{SJIF Impact Factor 2021: 8.013| ISI I.F.Value:1.241| Journal DOI: 10.36713/epra2016 ISSN: 2455-7838(Online) EPRA International Journal of Research and Development (IJRD)

Similarly, there exists positive and moderate correlation between the LGU's functions in the preservation of the culture in terms of laws implementation and the citizens' consciousness of the habits $(r=0.452, p=0.000)$. The relationship is significant. This means that the LGU's function in terms of laws implementation has been done well to preserve the consciousness of the culture of the citizens in terms of habits.

The LGUs' functions in the conservation of the culture in terms of laws implementation and the citizens' consciousness of values $(r=0.460, p=0.000)$ was denoted by a positive and moderate correlation. The relationship is significant This means that the LGU's functions in terms of laws implementation has been done well to preserve the consciousness of the culture of the citizens in terms of values.

Lastly, reflected in the descriptive tables are the extent to which the LGU promote the culture and the citizens' consciousness of the customs, habits, and values. It is interesting to note that the LGU's functions in the preservation of the culture of cultural heritage has positive and moderate correlation with the citizens' consciousness in terms of the customs $(r=0.472, p=0.000)$. The relationship is significant. This means that the LGU's function in terms of preservation of cultural heritage has been done well to preserve the consciousness of the culture of the citizens in terms of customs.

Similarly, there exists positive and moderate correlation between the LGU's functions in the preservation of the culture of cultural heritage and the citizens' consciousness in terms of the habits $(r=0.397, p=0.000)$. The relationship is significant. This means that the LGU's function in terms of preservation of cultural heritage has been done well to preserve the consciousness of the culture of the citizens in terms of habits.

The LGU's functions in the preservation of the culture in terms of cultural heritage and the citizens' consciousness of values $(r=0.503, p=0.000)$ was denoted by a positive and moderate correlation. The relationship is significant This means that the LGU's function in terms of preservation of cultural heritage has been done well to preserve the consciousness of the culture of the citizens in terms of values.

As it is presented in all of the data above, the LGU's functions have positive and moderate correlation to the preservation of the citizens' level of consciousness of its culture. Therefore, data were all "Significant".

The result of their study proves that LGUs have a huge function in the preservation of the consciousness of the culture of the citizens.

\section{CONCLUSION}

In the light of the findings of the study the following conclusions are given.

1. The best performed LGU's function identified by the respondents to preserve the culture is laws implementation which rated 4.73 followed by education which rated 4.33 , both are in a Very High Extend and lastly is the preservation of cultural heritage that rated 3.88 as High Extent.

2. The respondents are said to be most conscious in their culture in terms of both Habits and Values which rated 4.42 as Very High while customs rated 4.07 as High.

3. LGU's functions in the preservation of the culture provide a "positive relationship" to the citizens' consciousness of their culture. The hypothesis which stated that there is no significant relationship between the LGU's functions in the preservation of consciousness on the culture of its citizens is "not supported".

\section{RECOMMENDATION}

Based on the findings and conclusions presented, the researcher has arrived on the following recommendations.

1. To the students, being participative and having that eagerness to learn these things is expected to them. Experiencing while learning in all the programs being held in school can help them to expose themselves in improving their consciousness about their culture.

2. To the schools, having more activities and programs that highlights the rich culture of the country or of their local units can help the students be reminded of these things. The schools may integrate culture to their curriculum as one way of assuring the preservation of it.

3. To the educators, integrating some information about the different cultural facts is one of the good ways in helping the students be aware of their culture. Activities inside the classrooms or during discussion is one good opportunity to preserve the consciousness of culture of the citizens.

4. To the community, they may visit museums that can remind them of who they are and to learn more about their past. 


\title{
EPRA International Journal of Research and Development (IJRD)
}

\author{
Volume: 6 | Issue: 7 | July 2021
}

- Peer Reviewed Journal

5. To the local government units, they may pass more laws or ordinances like "Preserve Local Culture Act" that will directly protect the cultural heritage is important so that they will have the capability to control the modernizations of it. Building up museum is one good way of showing the citizens about the richness of the culture in their place. With this, the citizens will have the opportunity to learn more about their own culture.

6. To the Municipal Tourism, Culture and Arts Office, they may sponsor online activities like contests that may showcase the presentation of the local cultures of their citizens. Using different social media platforms nowadays is a good way of reaching all the citizens of their municipality. They may also put a "Local Tour Experience" where the tourists and even the local citizens can experience visiting the famous cites of the municipality.

7. To the future researchers who are interested to study about the preservation of culture, the researcher recommends the following considerations; (1) Qualitative type of research is the best type of research on this kind of topic. In this way, more personal and firsthand experience in the way of gathering data is necessary. (2) Consider having bigger and more diverse place where modernization is rising up. In this way, the future researcher will determine how the LGUs are giving considerations to their culture in spite of the modernization. (3) Working out with the questions and possible interviews, conversing using the mother tongue of the respondents is highly recommended. The researcher also recommended the following related topics; (1) Political Vision of the LGU Officials: Its Effect to the Current Situation of the Consciousness of the Culture of the Citizens. (2) Efforts in the Preservation of the Culture and Its Effect to the Modernization. (3) Level of Awareness to the Importance of the Preservation of Culture of the Citizens.

\section{REFERENCES}

1. Bailey, J. J.-C. (2011). Race and Ethnicity in the Field of Adult Education. International Encylopidia of Education.

2. Buckland. (2013). Cultural Heritage. Archives and Memory, 11-15.

3. Byer, A. (July 2017). The Importance of Law in Cultural Heritage Protection. NEXUS.

4. Cannizzaro, S. A. (September 2016). Culture as Habit, Habit as Culture: Instinct, Habituescence, Addiction

5. Cros, H. d. (February 2012). Intangible Cultural Heritage. Education and Museums.

6. Depcinski, M. (2019). Conservation in Museums. Global Archaelogy.

7. Douglas. (2001). Culture as Explanation: Cultural Concerns. Social and Behavioral Sciences

8. El-Saba, A. M. (February 2015). Philippines Culture and Tradition. Globalization Partners.

9. Gaivoron, N. (2018). Education is the Strongest Tool For Cultural Heritage Preservation. Culture Partnership.

10. Hania, U. A. (2012). Preserving Cultural Heritage Through Creative Industry.

11. Hays, J. (June 2015). Philippines. Facts and Details.

12. Holand, O. e. (December 2014). The Effects of Culture and Gender on Perceived Self-Other Similarity in Personality. Research in Personality, 13-21.

13. Islamoglu, O. (2018). The Importance of Culture Heritage Education in Early Ages. Ozgesever, 19-25.

14. Jhangiani, R. T. (August 2014). Principles of Social Pyschology. Principles of Social Psychology.

15. Lally, P. C. (October 2011). How are Habits Formed: Modeling Habit Formation in the real World. European Journal of Social Psychology, 40.

16. Lusig, M. (2013). Intercultureal Competence Interpersonal Communication Across Cultures.

17. Maiese, M. (February 2016). Causes of Disputes and Conflicts. Beyond Intractability.

18. Morris, M. (December 2013). Values as the Essence of Culture. Cross- Cultural Psychology, 14-24.

19. Obioha, E. (September 2012). The Role of Traditional Laws and Taboos in Wildife Conservation in the Oban Hill Sector of Cross River National Park, Nigeria. Human Ecology, 209-219.

20. Offorma, C. (2016). Culture in Curriculum Planning. International Journal of Curriculum and Instruction, 1-8.

21. Pernia, E. R. (March 2017). Promoting Phillipine Culture and Valiues.

22. Pisano, G. (2020). Cultural Values: Definition, Examples and Importance.

23. Rosenthal, N. (November 2011). Habit Formation. Sussex Directories.

24. Roth, S. (2013). Human Syastems Management. 32.

25. Sapic, S. (2018). The Influence of Habits and Customs as Elements of Culture on Consumer Behaviour in the Section of Tourism.

26. Stankova, M. V. (2015). Raising Cultural Awareness of Local Traditions Through Festival Tourism. Neofit Rilski, 11.

27. Timpack, A. (2020). The SIgnificance of Culture-Based Education in Philippines. The Knowledge Review. 


\section{EPRA International Journal of Research and Development (IJRD)}

Volume: 6 | Issue: 7 | July 2021

- Peer Reviewed Journal

28. Tsinopoulou, Z.-M. (January 2017). Preservation of Culture Heritage: The Role of Museum in the Protection, Conservation and Mangement of Cultural Collections.

29. Wages, J. (December 2017). Why Museums are Important.

30. Wamimbi, P. W. (February 2017). Culture Values Shape our Lives, Society.

31. Wood, W. R. (2016). Psychology of Habit . Annual Review of Psychology, 289-314.

32. Yenipinar, U. (2016). Festival as Culture Heritage: The Mesir Festival of Manisa. Global Issues and Trends in Tourism, 233-334.

33. Zimmermann, K. A. (July 2017). American Culture: Traditions and Customs of the United States. Live Science . 